\title{
Effects of organic liquid fertilizers on biological activities and fruit productivity in open-field cherry tomato
}

\author{
Hyun-Sug Choi ${ }^{1, *}$ \\ 1. Universidade Católica de Daegu - Horticultura - Gyeongsan - República da Coreia.
}

\begin{abstract}
This study evaluated the effects of liquid fertilizers (LF) with farm-derived renewable resources on biological activities and chemical attributes of the soil and fruit in an open-field tomato (Lycopersicon esculentum var. cerasiforme) experiment conducted in South Korea in the 2019 growing season. The LF treatments included bone+fish meal (BF), fish+phosphoric acid (FP), sesame oil (SO), starfish (SF), nontreatment (NT) as control, and oil cake (OC) as an organic fertilizer, fertigating two times per week during the growing season. The $\mathrm{pH}$ in LF ranged between 7.4 and 8.3 , and electrical conductivity in the LF was the highest on SF $\left(0.69 \mathrm{dS} \cdot \mathrm{m}^{-1}\right)$, SO $\left(0.64 \mathrm{dS} \cdot \mathrm{m}^{-1}\right)$, and BF $\left(0.45 \mathrm{dS} \cdot \mathrm{m}^{-1}\right)$. Total amount of total-N supplied was the highest for SF (679 mg.plant $\left.{ }^{-1}\right)$, SO (654 mg), and BF (333 mg). The number of some invertebrates was increased by the BF and SF treatments. Earthworm biomass was significantly increased by the SF treatment. The NT and OC treatments reduced operational taxonomic units and the richness estimator of Chao1 and ACE. Seasonal SPAD and PS II values in the leaves were reduced on the FP-plants on 45 and 60 days after fertigation. The SF treatment increased fruit fresh weight and fruit yield to $4.2 \mathrm{~kg}$ per plant, with similar results observed for BF-treated plants. Fruit yield efficiency was improved by the BF treatment, followed by SO and SF among all the treatment. Starfish would be the promising LF for use as a supplemental nutrient amendment to increase agroecosystem health, nutrient availability, and fruit productivity.
\end{abstract}

Key words: earthworms, fertigation, invertebrate, micronutrient, pyrosequencing.

\author{
Received: \\ Feb. 21, 2020 \\ Accepted: \\ Jun. 8, 2020 \\ Section Editor: \\ Hector Valenzuela \\ ${ }^{*}$ Corresponding author: \\ hchoiuark@gmail.com
}

\section{INTRODUCTION}

Tomato (Lycopersicon esculentum var. cerasiforme) production and consumption in the last 20 years has consistently ranked highest in South Korea due to the nutritive value and functional properties of the fruit and use on a variety of ingredients (Rural Development Administration 2019). However, production has decreased slightly in recent years due to increasing demand for imports of other tropical fruit commodities and concerns of environmental pollution from the intensive application of synthetic chemicals. Organic tomato production would be expected to offer high premium prices and biodiversity conservation, leading to a more sustainable system (Luttikholt 2007). This has brought the opportunity for African and Southeast Asian countries to produce organic tomatoes, contributing to an increase in the cultivation and production income (Badgley et al. 2007). Organic cultivation excludes the use of inorganic chemical additives, synthetic fertilizers, insecticides, and herbicides and allows natural resource extraction, improving soil biodiversity and declining hazards to human health (Luttikholt 2007).

Organic tomatoes can be cultivated year-round in controlled system greenhouses, but open field production provides easy access for small-scale rural or periurban farms to contribute to the local food system (Luttikholt 2007). Open-field tomato plants have a long production cycle from planting to harvest, requiring supplemental fertilizer to sustain vegetative and reproductive growth. Additional fertilization using organic nutrient sources is typically employed in local regions of South 
Korea, with fertigation using farm-derived renewable resources used as a substitution of conventional inorganic fertilizers (An et al. 2012). Liquid fertilizers (LF) from animal resources were mostly made from bone and blood meal and recycled marine by-products, with resources from a wide variety of plant organs and tissues (An et al. 2012; Hernández-Herrera et al. 2014; Parr et al. 1986; Rosen and Allan 2006). Both animal and plant extracts are readily available for cash crops, containing various concentrations of mineral nutrients, and solubilized at different rates of mineralization, resulting in asynchronization of nutrient availability between soil and plants as well as having differential effects on the soil fauna community (An et al. 2012).

Biological parameters indicated the presence of a community of microorganisms and an abundance of meso- and macroinvertebrates and their composition, with the general effects on organic agriculture already having been reviewed using a meta-analysis (Bengtsson et al. 2005). Effects on the diversity of invertebrates in organic and conventional farming methods for horticultural crops have been studied for red peppers (Lee et al. 2013), tomatoes (Yardim and Edwards 2003), grapes (Thomson and Hoffmann 2007), apples (Miñarro et al. 2009), kiwifruits (Todd et al. 2011), and pears (Kim et al. 2011; Oh et al. 2014). The effects of organic-based fertilizers as a supplemental fertilization on fruit productivity and soil biological attributes are little known for the field production of tomatoes.

The current study was initiated to determine the effect of organic farm-derived LF on the biological attributes and performance of open-field tomatoes.

\section{MATERIAL AND METHODS}

\section{Plot layout}

The experiment was performed on a private fruit and vegetable farm located in Gumi-si, South Korea $\left(36^{\circ} \mathrm{N} / 128^{\circ} 20^{\prime} \mathrm{E}\right)$ in 2019. Lettuce, cabbage lettuce, carrot, and sweet potato on the farmland had been environmentally-friendly cultivated on the land prior to starting this experiment, which was annually applied with manure compost (pig manure $30 \%$, chicken manure $15 \%$, cow manure $10 \%$, rice bran $15 \%$, saw dust $20 \%$, bark $10 \%$, organic matter $30 \%$, Gyeongju, South Korea). For the current experiment, 20,000 kg of manure compost per hectare were applied under shallow cultivation as a basal application of the compost according to the mineral nutrient requirements of tomato (Rural Development Administration 2019). The soil pH and electrical conductivity in the plots were, respectively, 7.2 and $0.2 \mathrm{~d} \cdot \mathrm{S} \cdot \mathrm{m}^{-1}$, with T-N, P, and K levels less than $0.01 \%$. The regional average temperature and the amount of precipitation were $23.3^{\circ} \mathrm{C}$ and $759.7 \mathrm{~mm}$, respectively, with $22.1{ }^{\circ} \mathrm{C} / 828.5 \mathrm{~mm}$ of the average in the last 30 years from 1981 to 2010 (Korea Meteorological Administration 2019). The soil type in the treatment plots was sandy-loam (sand $57.4 \%$, silt $30.0 \%$, and clay $12.6 \%$ ) moderately well-watered and aerated in the root zone.

'Daechu' cherry tomato seedlings were planted at a density of $45 \mathrm{~cm}$ between plants and $90 \mathrm{~cm}$ between plant rows on May 3rd 2019. Black plastic mulch covered the plant rows to suppress weed and insect damage, which was then halfcovered and not mown from early June to September, with the final harvest used to investigate the biological parameters on each treatment plot. Water was supplied for the plants using drip-irrigation when precipitation was not recorded for three consecutive days. Insect and disease were organically controlled during the growing season.

Four different liquid fertilizers (LF) were selected through a pretest that evaluated the most efficient LF used in each leading fruit and vegetable farm in South Korea. The LF made with farm-derived renewable resources included bone+fish meal (BF), fish+phosphoric acid (FP), sesame oil (SO), and starfish (SF), with a nontreatment (NT) as control and oil cake (OC; T-N 4.6\%, P 1.4\%, K 1.0\%, OM 70\%, Chamjoa oil cake, Farmhannong Co., Seoul, Korea) as a typical organic fertilizer source, fertigating with a 100 times dilution rate. The LF and organic fertilizer treatments were applied in addition to the basal application of compost.

\section{Liquid fertilizers treatment}

Bone+fish meal consisted of bone meal, $16.5 \%$, fish residue, $16.5 \%$, effective microorganisms (EM), 0.7\%, molasses, $0.2 \%$, and water, $66.1 \%$ with a 3 -month fermentation. Fish+phosphoric acid was made with fish extract, $2.0 \%$, molasses, $2.0 \%$, active 
phosphoric acid, $2 \%$, and water, $94 \%$ with a 6 -month fermentation. Sesame oil was fermented with sesame oil, $32.7 \%$, sea salt, $0.7 \%$, humus, $1.3 \%$, and water, $65.3 \%$ for 3 -months. Starfish was made with starfish, $40.3 \%$, seaweed, $10.1 \%$, molasses, $3.4 \%$, EM, $0.2 \%$, humus, $0.8 \%$, and water, $45.2 \%$ with a 3 -year fermentation.

Each plant was fertigated with $330 \mathrm{~mL}$ of the LF two times per week using a plastic cup and received approximately $11.0 \mathrm{~L}$ from two weeks after planting until the final harvest.

\section{Nutrient analysis}

Chemical components in the LF were analyzed according to the Rural Development Administration protocols (RDA 2010), with a pHmeter (FIVEEAST FE20, Mettler Tonedo CO., Jiangsu, China) and electrical conductivity (EC) using an EC meter (HI 2315 Conductivity Meter, Hanna CO., Seoul, Korea). Total nitrogen (T-N) concentration in the LF was analyzed using a CN analyzer (Vario MAX CN, Elementar CO., Langenselbold, Germany), available phosphorous (P) with a UV-visible spectrophotometer (UV-2450, Shimadzu, Tokyo, Japan), and exchangeable nutrient concentrations with an ICP-AES (Simultaneous ICP Spectrometer, SPECTRO Analytical Instruments GmbH CO., Baden-Württemberg, Germany).

Soil organic matter (OM) contents at a depth of 0 to $20 \mathrm{~cm}$ on August and October were estimated by calculating the organic carbon (C) through OM oxidized by $\mathrm{K}_{2} \mathrm{Cr}_{2} \mathrm{O}_{7}$ following the Tyurin method. Soil T-N concentrations were analyzed with a CN analyzer and available $\mathrm{P}_{2} \mathrm{O}_{5}$ with spectrophotometry according to the RDA protocols (RDA 2010). Exchangeable nutrient concentrations were also analyzed with an atomic absorption spectrometer analyzer, including for essential micronutrients.

Soil water content and soil temperature were measured at a depth of 0 to $10 \mathrm{~cm}$ between 50 and 100 days after fertigation (DAF) two times per week using a soil moisture meter (GMK-770S, G-WON Hitech CO., LTD., Seoul, Korea).

\section{Biological analysis}

In August top growth biomass was collected from an area of $40 \mathrm{~cm}^{2}$, the samples were placed in plastic bags, air dried $70{ }^{\circ} \mathrm{C}$ for 7 days, and dry weight (DW) was determined.

Earthworms were visually counted and their length and fresh weight (FW) were determined by excavating with a shovel $40 \mathrm{~cm}^{3}$ of soil volume (width $\times$ depth), from the same location that received the fertigation in August.

A pit fall trap with a plastic circle cup $(9.5 \mathrm{~cm}$ diameter and $7.5 \mathrm{~cm}$ length) was buried in the mid-point of the soil between the plants per plot to collect ground-dwelling invertebrates at the end of the two-week period in June and September. Each trap was filled with a preservation solution of a 1:1 mixture of ethyl alcohol and ethyl glycol to prevent spoilage of the captured invertebrates. The captured invertebrates on each treatment plot were visually sorted and identified for a total of 27 species in June and 26 species in September.

The dominance index was calculated from the two most abundant invertebrate species by dividing by total number of invertebrate species collected in June and September, respectively (Oh et al. 2014).

The 16S rRNA gene fragments of the bacterial community sequencing data were analyzed using the Mothur software package to describe operational taxonomic units (OTUs), Good's nonparametric coverage, Chaol, ACE, Shannon, and inverse Simpson on each treatment plot (Schloss et al. 2009).

\section{Plant performance}

SPAD 502 chlorophyll meter readings (Minolta, Tokyo, Japan) were taken weekly to determine relative foliar chlorophyll concentrations from 30 to 120 DAF. Photosystem II activity in the leaves taken for SPAD readings was determined using a chlorophyll fluorescence measurement with a FP100 (FluorPen P100, Photon System Inc., Drasov, Czech Republic).

Tomato plants, including roots, shoots, leaves, and fruits, were fully harvested on $120 \mathrm{DAF}$, dried in an oven at $70^{\circ} \mathrm{C}$ for 7 days, and vegetative (root+shoot+leaf) and fruit dry weight (DW) were determined. Fruit yield efficiency was indicated as a percentage of fruit DW divided by vegetative DW. 
Fruit were harvested for nine times during the maturation. They were counted, and fresh weight (FW) was determined to calculate accumulated fruit yield. Ten fruits on each treated-plant were sampled for fruit quality analysis on 120 DAF, in the final harvest. Fruit diameter and length were measured using a digital caliper (Mitutoyo Corp., Takatsu-ku, Japan). Fruit soluble solid contents (SSC) were then measured on the middle point of the fruit using a hand-held refractometer (GMK-706R, G-WON Hitech CO., LTD., Seoul, Korea). Fruit firmness was measured using a hand-held penetrometer with $3.0 \mathrm{~mm}$ diameter tip (FR-5105, Lutron electronic enterprise CO., LTD., Taipei, Taiwan). Fruit surface color parameters, $\mathrm{L}^{*}$ (light), $\mathrm{a}^{*}$ (red), and $\mathrm{b}^{*}$ (blue), were determined using a color difference meter (FR-5105, X-Rite, INC., Grand Rapids, USA).

\section{Statistical analysis}

Treatments were randomly assigned to three-plant plots with a completely randomized block design, and each treatment consisted of three plots (three replications). Experimental unit (data unit) was a single plant in the center of the triad and the others were guard plants to prevent nutrient contamination between the plots. Treatment means were compared using an analysis of variance (ANOVA). All statistical analyses were performed using SAS to determine treatment differences with Duncan's multiple range test at the 0.05 level of significance.

\section{RESULTS AND DISCUSSION}

\section{Chemical components of LF}

The $\mathrm{pH}$ values in LF ranged between 7.4 and 8.3, with the lowest values observed on SO (Table 1). The highest EC level in the LF was observed by SF $\left(0.69 \mathrm{dS} \cdot \mathrm{m}^{-1}\right), \mathrm{SO}\left(0.64 \mathrm{dS} \cdot \mathrm{m}^{-1}\right)$, and BF $\left(0.45 \mathrm{dS} \cdot \mathrm{m}^{-1}\right)$. The FP treatment had relatively low EC of $0.30 \mathrm{dS} \cdot \mathrm{m}^{-1}$ due to its $94 \%$ dilution with water during fermentation. The nutrient levels among the treatment plots were sufficient to meet the nutritional needs of plants, based on crop recommendations in South Korea (RDA 2019).

The total amount of T-N supplied during the growing season was the highest for SF ( $679 \mathrm{mg} / \mathrm{plant}$ ), followed by and SO (654 mg), BF (333 mg), OC (153 mg), and FP (133 mg; Table 1). Fish+phosphoric acid supplied greater amount of P (488 mg.plant $\left.{ }^{-1}\right)$ and $\mathrm{Ca}(1,485 \mathrm{mg})$, with high amount of Fe $(576 \mathrm{mg}), \mathrm{Mn}(22 \mathrm{mg})$, and $\mathrm{Cu}(5 \mathrm{mg})$, which can inhibit root respiration and biological activities if they are in very high concentrations in the soil (Marschner 2012). Bone+fish meal supplied relatively higher levels of $\mathrm{K}(2,295 \mathrm{mg})$ and B $(99 \mathrm{mg})$, with high accumulation of $\mathrm{Mg}$ and Zn observed for SO.

No significant differences among the treatment plots were found with respect to organic matter content, soil temperature, and soil moisture during the growing season (data not shown).

Table 1. Nutrient contents in liquid fertilizers with farm-derived renewable resources used in an experiment plot, Gumi-si, South Korea, 2019.

\begin{tabular}{|c|c|c|c|c|c|c|c|c|c|c|c|c|}
\hline \multirow{2}{*}{ Treatment } & \multirow{2}{*}{$\mathrm{pH}$} & \multirow{2}{*}{$\begin{array}{c}E C \\
(\mathrm{dS} / \mathrm{m})\end{array}$} & T-N & $\mathbf{P}$ & K & $\mathrm{Ca}$ & $\mathrm{Mg}$ & $\mathrm{Fe}$ & $M n$ & $\mathrm{Zn}$ & $\mathrm{Cu}$ & B \\
\hline & & & \multicolumn{10}{|c|}{ (mg/plant) } \\
\hline NT & $8.5 \mathrm{a}$ & $0.25 \mathrm{~b}$ & $0.01 \mathrm{f}$ & $0.01 \mathrm{~d}$ & $0.01 \mathrm{~d}$ & $285 f$ & $109 \mathrm{e}$ & $0.01 \mathrm{f}$ & $4 c$ & $1 \mathrm{f}$ & $0.1 \mathrm{f}$ & $0.2 \mathrm{e}$ \\
\hline$O C$ & $8.3 \mathrm{a}$ & $0.27 b$ & $153 d$ & $147 c$ & $2,149 \mathrm{c}$ & $1,247 c$ & $110 \mathrm{e}$ & $252 b$ & $3 d$ & $33 c$ & $2 c$ & $82 d$ \\
\hline $\mathrm{BF}$ & $8.1 \mathrm{a}$ & $0.45 a b$ & $333 c$ & $158 c$ & $2,295 \mathrm{a}$ & $1,184 \mathrm{~d}$ & $165 c$ & $33 \mathrm{e}$ & $2 \mathrm{e}$ & $3 e$ & $1 \mathrm{~d}$ & $99 a$ \\
\hline $\mathrm{FP}$ & $8.2 \mathrm{a}$ & $0.30 \mathrm{~b}$ & $133 \mathrm{e}$ & $488 a$ & $2,189 \mathrm{bc}$ & $1,485 \mathrm{a}$ & $176 b$ & $576 a$ & $22 a$ & $48 \mathrm{~b}$ & $5 a$ & $87 c$ \\
\hline so & $7.4 \mathrm{~b}$ & $0.64 a$ & $654 b$ & $172 \mathrm{c}$ & $2,251 a b$ & $1,309 \mathrm{~b}$ & $257 a$ & $147 c$ & $4 c$ & $60 a$ & $1 \mathrm{~d}$ & $88 \mathrm{~b}$ \\
\hline SF & $8.2 \mathrm{a}$ & $0.69 a$ & $679 a$ & $293 \mathrm{~b}$ & $2,262 a b$ & $1,034 \mathrm{e}$ & $136 d$ & $108 d$ & $7 b$ & $15 d$ & $4 \mathrm{~b}$ & $86 \mathrm{c}$ \\
\hline
\end{tabular}

The presented values were results from the nutrient analysis in 100 times dilution with each liquid fertilizer. Means comparisons among treatments within a column by Duncan's new multiple range test; means followed by different letters are significantly different, $5 \%$ level. NT: nontreatment, OC: oil cake, BF: bone+fish meal, FP: fish+ phosphoric acid, SO: sesame oil meal, SF: starfish. 


\section{Biological parameters}

A lower vegetation biomass was observed on the NT plots (Fig. 1a), probably due to receiving lower amounts of mineral nutrients compared to the LF plots. Length and weight of earthworms were greatly increased by SF treatment (Fig. $1 \mathrm{~b}$ and c). This would potentially have reduced soil contamination and environmental disturbance as earthworms are important sustainable bioindicators to monitor soil environments (Paoletti et al. 1998; Paoletti 1999).

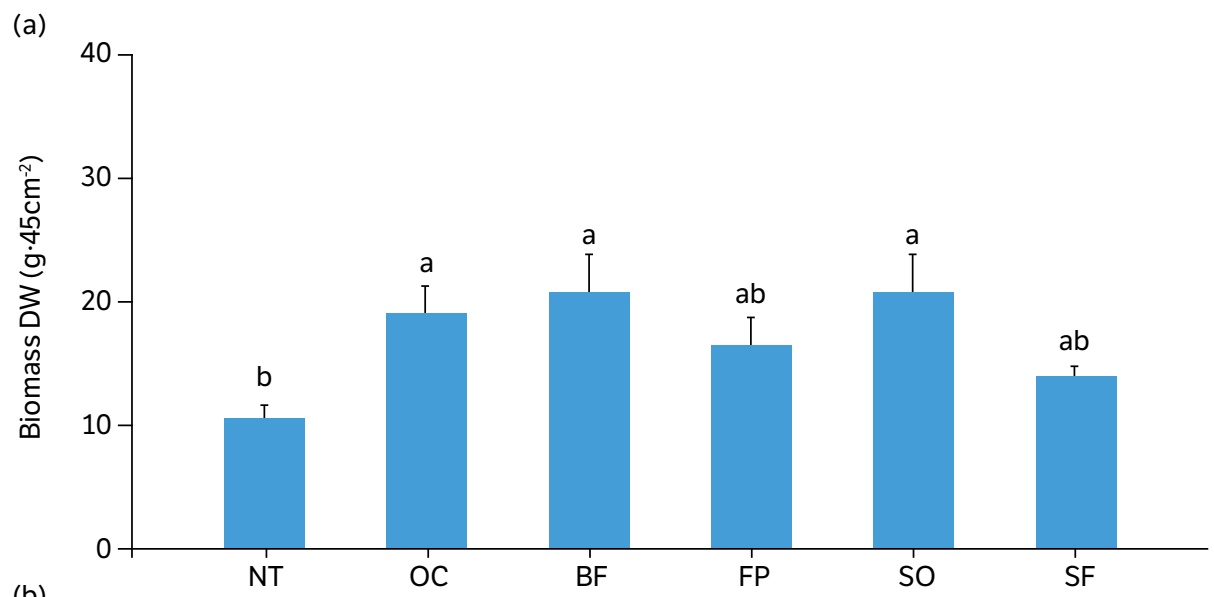

(b)

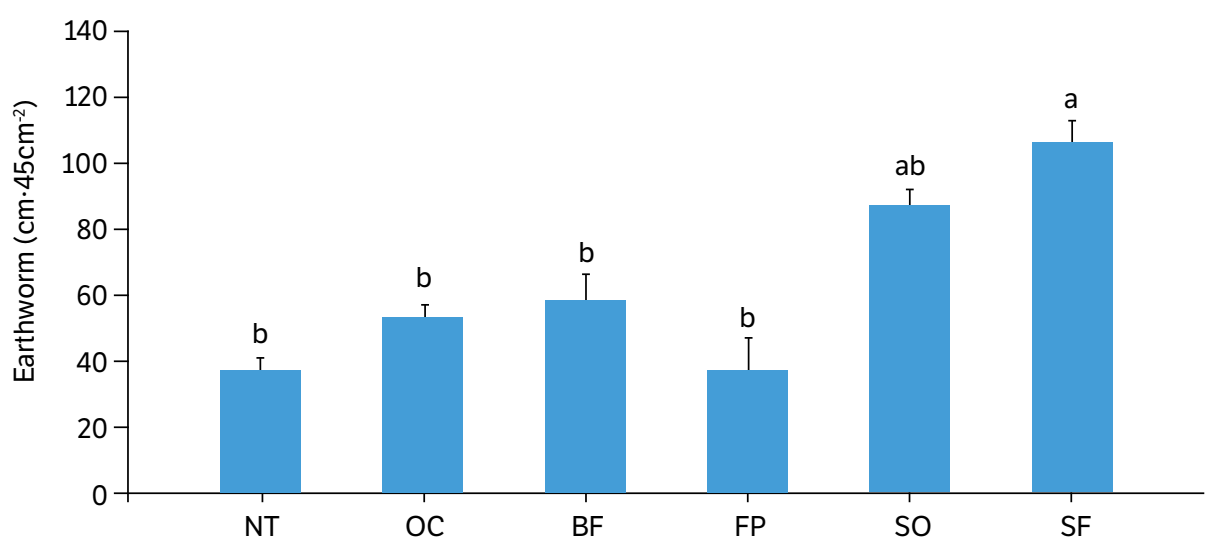

(c)

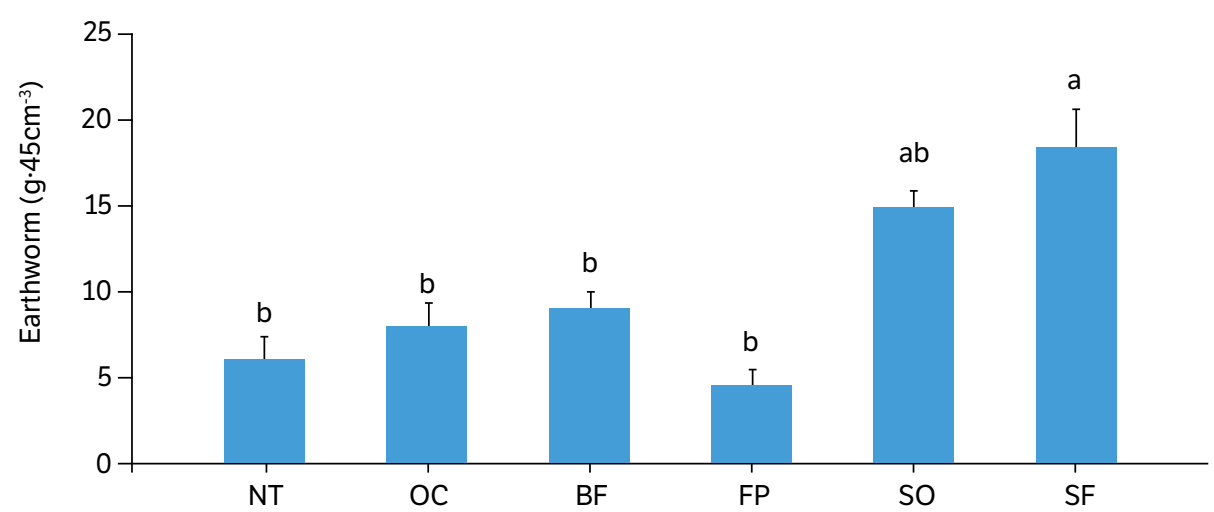

Figure 1. Biomass accumulation (a), length of earthworms (b), and fresh weight of earthworms (c) as affected by liquid fertilizers in a cherry tomato field, Gumi-si, South Korea, 2019.

NT: nontreatment, OC: oil cake, BF: bone+fish meal, FP: fish+phosphoric acid, SO: sesame oil meal, SF: starfish. Different lower-case letters on each datum point for each phase indicate significant differences as determined by Duncan's multiple range test at $\mathrm{p} \leq 0.05$. Bars represent error of the means. 
The number of invertebrates was increased by BF in June (Fig. 2a) and by BF and SF in September (Fig. 2b), but reduced by the FP treatment which is likely associated with the lower concentration of T-N and higher Fe, Mn, and $\mathrm{Cu}$ observed in this treatment. The population of invertebrates in September was overall approximately two times higher than June likely due to increasing litter and grass cover and to the more moderate and lower soil temperatures observed in September. High levels of fertilization increased population of invertebrate herbivores living on plants in relation to the availability of T-N in the invertebrates or in the stressed plants (Ahn et al. 2017; Eaten et al. 2004; Feber et al. 2015; Yardim and Edwards 2003). The invertebrate dominance index was not significantly different among the treatment plots, but the springtail (Entomobrya sp.), pill bug (Armadillidium vulgare), and giant earwig (Labidura riparia japonica) were mostly observed in the plots (data not presented). The springtails were greater in the BF plots, followed by SF and SO plots in June (Fig. 2c). The springtails are known as primary decomposers, are one of the most abundant invertebrates in S. Korea (Ahn et al. 2017; Lee et al. 2013), and are the most numerous mesoinvertebrates in the forest floor (Eaten et al. 2004). The number of pill bugs highly increased on SF, BF, and SO plots for September (Fig. 2d), which likely responded to the organic matter supplied by those LF treatments. The pill bug is not categorized as a pest, in particular promotes the growth of plants, naturally till the soil surface, and contributes to soil aeration and water infiltration (Refinetti 1984).

The number of operational taxonomic units (OUT) was not likely to be enhanced by the NT and OC treatments, which resulted in a low Good's coverage and richness estimator of Chaol and ACE with respect to the bacterial community

(a)

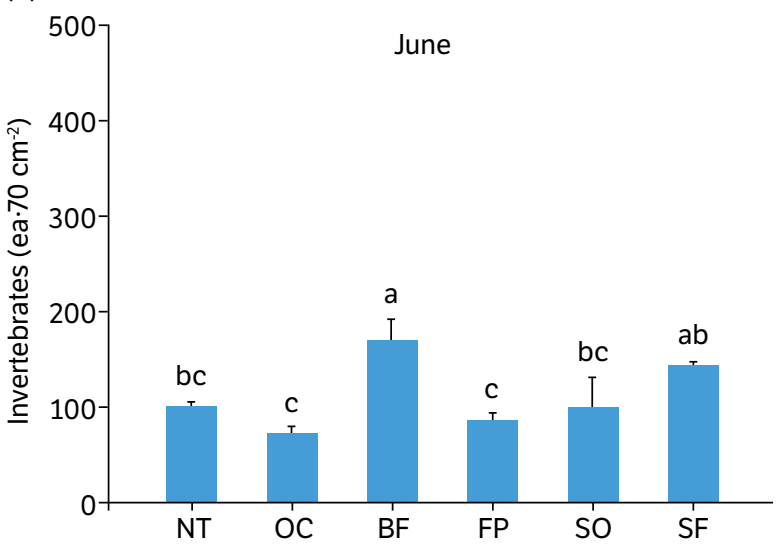

(c)

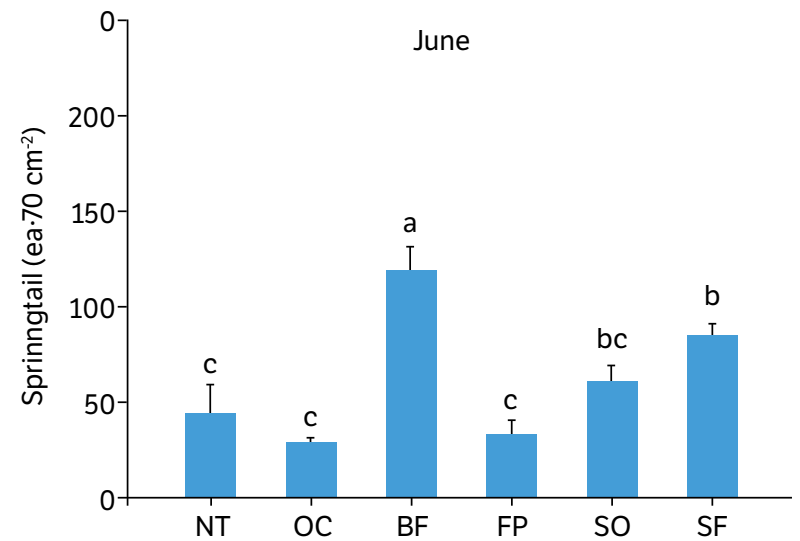

(b)

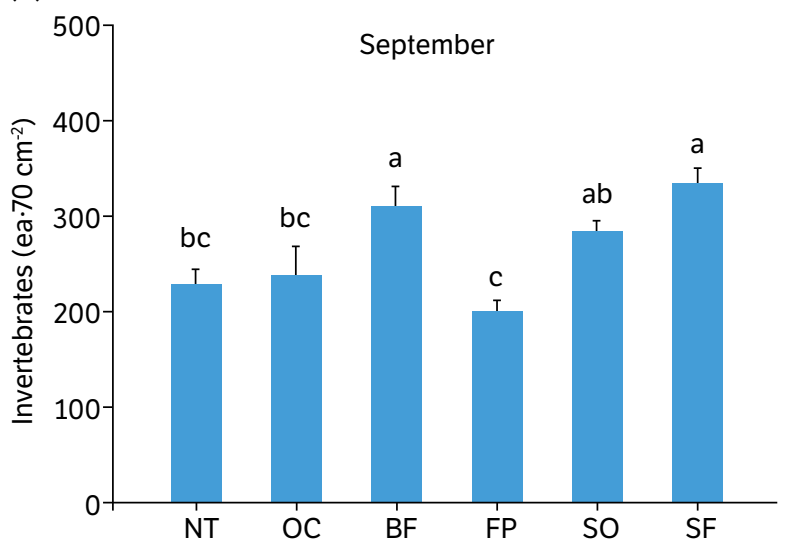

(d)

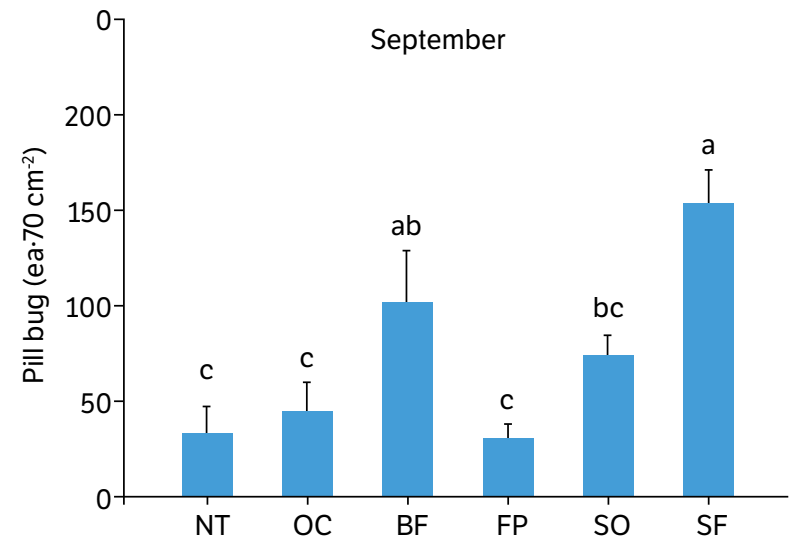

Figure 2. Total number of invertebrates on June (a) and September (b), and springtail on June (c) and pill bug on September (d) as affected by liquid fertilizers in a cherry tomato field, Gumi-si, South Korea, 2019.

NT: nontreatment, OC: oil cake, BF: bone+fish meal, FP: fish+phosphoric acid, SO: sesame oil meal, SF: starfish. Different lower-case letters on each datum point for each phase indicate significant differences as determined by Duncan's multiple range test at $p \leq 0.05$. Bars represent error of the means. 
(Table 2). The soil microbial biomass improves nutrient availability and contributes plant growth-regulating substances in the rhizosphere through mineralization or microbial biomass turnover, directly influencing plant growth (Arancon et al. 2005). The phylum Proteobacteria, Actinobacteria, and Acidobacteria mostly occupied between $65-68 \%$ of the $16 \mathrm{~S}$ rRNA gene sequence obtained from the SF and NT treatment plots (Fig. 3), which represent common phyla observed in arable land (Chaparro et al. 2014; Oh et al. 2014).

\section{Plant performance}

Seasonal SPAD values in the leaves were significantly lower on the NT-plants on 45 and 60 DAF than those values observed on the LF plants (Fig. 4a). PS II activity, an indicator of net photosynthesis, was reduced on all the treated plants on 75 DAF (Fig. 4b) when high soil temperature and low soil water content were experienced.

Fruit length was not significantly different between the LF-treated plants (Table 3). A smaller fruit diameter was observed on the NT, BF, and FP plants. The SF treatment increased the average fruit FW and resulted in the greatest fruit yield of $4.2 \mathrm{~kg}$ per plant, similarly shown for BF and SO plants. The NT and OC treatments tended to promote vegetative growth (data not shown), which likely suppressed reproductive growth and fruit yield efficiency as previously observed on cherry tomato with slurry composting and biofiltration (Kim et al. 2013).

The FP and OC treatments had greater fruit SSC while SO, OC, FP, and BF showed a higher fruit surface color of red $\left(\mathrm{a}^{*}\right)$, with the lowest values observed on the NT fruits (Table 3). A low soil EC, as observed in the FP and OC treatments, may have facilitated water transport into the root and fruit, improving the fruit SSC and coloring in these treatments (Kim et al. 2013; Park et al. 2015). Additionally, high concentrations of P and other essential metal mineral nutrients in the FP material would have influenced the components of DNA, RNA, cell membrane, and essential energy transfer molecules, regulating carbohydrate synthesis and movement (Marschner 2012).

Table 2. Bacterial community as affected by liquid fertilizers in a cherry tomato field, Gumi-si, South Korea, 2019.

\begin{tabular}{|c|c|c|c|c|c|c|}
\hline \multirow[b]{2}{*}{ Treatment } & \multirow{2}{*}{$\begin{array}{l}\text { Number } \\
\text { of OTUs }\end{array}$} & \multirow{2}{*}{$\begin{array}{l}\text { Good's } \\
\text { coverage }\end{array}$} & \multicolumn{2}{|c|}{ Richness estimator } & \multicolumn{2}{|c|}{ Diversity index } \\
\hline & & & Chao1 & ACE & Shannon & $\begin{array}{l}\text { Inverse } \\
\text { Simpson }\end{array}$ \\
\hline NT & 4,575 & 97.0 & 4,792 & 4,957 & 7.2 & 0.004 \\
\hline $\mathrm{OC}$ & 4,411 & 97.0 & 4,591 & 4,727 & 7.2 & 0.003 \\
\hline $\mathrm{BF}$ & 5,584 & 98.9 & 5,790 & 5,992 & 7.2 & 0.005 \\
\hline $\mathrm{FP}$ & 5,058 & 99.0 & 5,226 & 5,734 & 7.2 & 0.003 \\
\hline SO & 5,166 & 98.9 & 5,341 & 5,501 & 7.2 & 0.003 \\
\hline SF & 5,071 & 98.9 & 5,228 & 5,382 & 7.3 & 0.003 \\
\hline
\end{tabular}

NT: nontreatment, OC: oil cake, BF: bone+fish meal, FP: fish+ phosphoric acid, SO: sesame oil meal, SF: starfish. OTUs: operational taxonomic units.

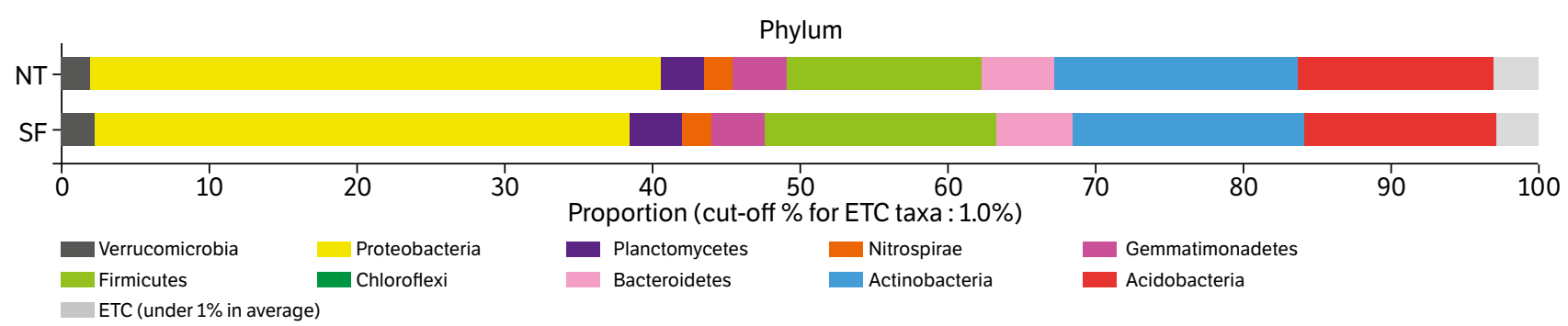

Figure 3. Relative abundance of the dominant bacterial phyla as affected by liquid fertilizers with NT (nontreatment) and SF (starfish) in a cherry tomato field, Gumi-si, South Korea, 2019. 

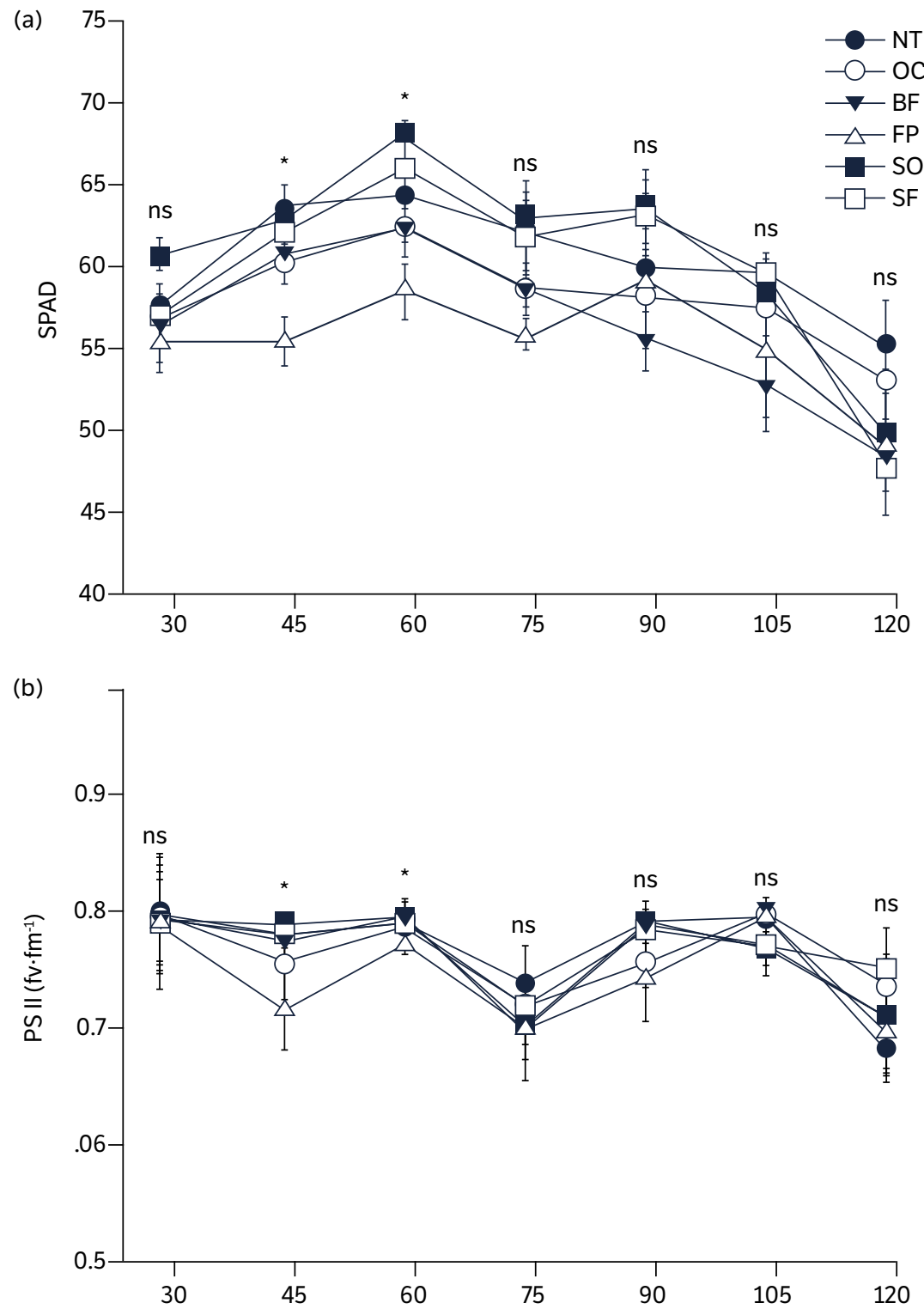

Figure 4. Foliar SPAD (a) and PS II values (b) as affected by liquid fertilizers in a cherry tomato field, Gumi-si, South Korea, 2019.

NT: nontreatment, OC: oil cake, BF: bone+fish meal, FP: fish+phosphoric acid, SO: sesame oil meal, SF: starfish. *Significantly different mean values at $\mathrm{p} \leq 0.05$. ns, not significantly different.

Table 3. Fruit characteristics as affected by liquid fertilizers in a cherry tomato field, Gumi-si, South Korea, 2019.

\begin{tabular}{|c|c|c|c|c|c|c|c|c|c|c|}
\hline \multirow{2}{*}{ Treatment } & \multicolumn{2}{|c|}{ Fruit size $(\mathrm{mm})$} & \multirow{2}{*}{$\begin{array}{l}\text { Avg. FW } \\
\text { (g) }\end{array}$} & \multirow{2}{*}{$\begin{array}{l}\text { Accumulated } \\
\text { fruit yield } \\
\text { (kg/plant) }\end{array}$} & \multirow{2}{*}{$\begin{array}{c}\text { Fruit yield } \\
\text { efficiency } \\
(\%)\end{array}$} & \multirow{2}{*}{$\begin{array}{c}\text { SSC } \\
\left.\text { ( }{ }^{\circ} \text { Brix }\right)\end{array}$} & \multirow{2}{*}{$\begin{array}{l}\text { Firmness } \\
(\mathrm{N})\end{array}$} & \multicolumn{3}{|c|}{ Color } \\
\hline & Length & Diameter & & & & & & $\mathbf{L}$ & a & b \\
\hline NT & $36.3 a$ & $26.6 \mathrm{~b}$ & $9.9 \mathrm{c}$ & $3.1 \mathrm{~b}$ & $2.4 \mathrm{c}$ & $6.2 \mathrm{c}$ & $1.9 \mathrm{c}$ & $33.5 \mathrm{a}$ & $24.0 \mathrm{~b}$ & $28.5 \mathrm{a}$ \\
\hline OC & $36.7 a$ & $28.5 \mathrm{a}$ & $11.2 \mathrm{~b}$ & $2.9 \mathrm{~b}$ & $2.4 \mathrm{c}$ & $7.2 \mathrm{a}$ & $2.3 \mathrm{bc}$ & $32.6 a b$ & $27.8 \mathrm{a}$ & $31.3 \mathrm{a}$ \\
\hline $\mathrm{BF}$ & $35.4 a$ & $28.0 \mathrm{ab}$ & $11.0 \mathrm{~b}$ & $4.5 a$ & $9.9 a$ & $6.6 \mathrm{~b}$ & $2.3 \mathrm{bc}$ & $48.0 \mathrm{~b}$ & $26.1 \mathrm{ab}$ & $28.3 a$ \\
\hline FP & $35.5 \mathrm{a}$ & $26.9 \mathrm{~b}$ & $10.5 b c$ & $3.0 \mathrm{~b}$ & $6.7 \mathrm{bc}$ & $7.3 a$ & $2.9 \mathrm{a}$ & $32.6 a b$ & $27.0 \mathrm{a}$ & $31.0 \mathrm{a}$ \\
\hline so & $38.0 \mathrm{a}$ & $29.0 \mathrm{a}$ & $11.1 \mathrm{~b}$ & $3.7 a b$ & $8.2 a b$ & $6.8 \mathrm{~b}$ & $2.6 a b$ & $33.6 a$ & $28.1 \mathrm{a}$ & $30.0 \mathrm{a}$ \\
\hline SF & $37.7 a$ & $28.4 \mathrm{a}$ & $14.6 \mathrm{a}$ & $4.2 \mathrm{a}$ & $8.6 a b$ & $6.5 b$ & $2.8 \mathrm{a}$ & $32.9 \mathrm{ab}$ & $23.8 b$ & $28.7 \mathrm{a}$ \\
\hline
\end{tabular}

Means comparisons among treatments within a column by Duncan's new multiple range test; means followed by different letters are significantly different, $5 \%$ level. NT: nontreatment, OC: oil cake, BF: bone+fish meal, FP: fish+ phosphoric acid, SO: sesame oil meal, SF: starfish. 
Fruit firmness was increased by the FP and SO treatments, likely supplying higher amounts of Ca. Fruit firmness has been positively correlated to fruit Ca concentrations because it is a component of the cell wall structure (Marschner 2012). However, the SF treatment with a low Ca supplement also enhanced fruit firmness, probably due to a greater presence of polysaccharides and plant growth stimulants in the seaweed (Hernández-Herrera et al. 2014), which are main components of the SF material.

The LFs with a $100 \times$ dilution influenced soil macroinvertebrates, mesoinvertebrates, and bacteria levels as well as vegetation biomass among all variables (Table 4). The presence of macro- and mesoinvertebrates is particularly important for organic farming systems because control of herbivores depends on high predator activity (Caprio et al. 2015; Yardim and Edwards 2003).

Table 4. Analysis of variance for biological parameters and plant performance as affected by electrical conductivity (EC) and T-N in liquid fertilizers in a cherry tomato field, Gumi-si, South Korea, 2019.

\begin{tabular}{|c|c|c|c|c|c|c|c|c|c|}
\hline \multicolumn{2}{|c|}{ Variables } & \multirow{2}{*}{$\begin{array}{c}\begin{array}{c}\text { Length of } \\
\text { earthworm }\end{array} \\
\star \star\end{array}$} & \multirow{2}{*}{$\begin{array}{c}\begin{array}{c}\text { Weight of } \\
\text { earthworm }\end{array} \\
\star \star\end{array}$} & \multirow{2}{*}{$\begin{array}{c}\text { Invertebrate, } \\
\text { September } \\
\star\end{array}$} & \multirow{2}{*}{$\begin{array}{c}\text { No. Pill bug } \\
\star\end{array}$} & \multirow{2}{*}{$\begin{array}{c}\begin{array}{c}\text { No. } \\
\text { Springtail }\end{array} \\
\text { ns }\end{array}$} & \multirow{2}{*}{$\begin{array}{c}\begin{array}{c}\text { Vegetative } \\
\text { DW }\end{array} \\
\star \star\end{array}$} & \multirow{2}{*}{$\begin{array}{c}\text { Fruit length } \\
\text { ns }\end{array}$} & \multirow{2}{*}{$\begin{array}{c}\begin{array}{c}\text { Yield } \\
\text { efficiency }\end{array} \\
\mathrm{ns}\end{array}$} \\
\hline & $P$ & & & & & & & & \\
\hline 20 & Type & L & L & L & L & - & $\mathrm{Q}$ & - & - \\
\hline \multirow{2}{*}{$\mathrm{T}-\mathrm{N}$} & $P$ & $\star \star$ & $\star \star$ & * & * & & ns & * & * \\
\hline & Type & L & L & $\mathrm{L}$ & L & $\mathrm{Q}$ & - & $\mathrm{Q}$ & $\mathrm{Q}$ \\
\hline
\end{tabular}

* ** Significantly different means among treatments at $\mathrm{p}<0.05$ and 0.01 , respectively. ns, not significantly different. L and Q indicated positive linear and quadratic regression, respectively.

\section{CONCLUSION}

Organic amendments help to improve soil fertility and sustainability by improving biological activity, nutrient mineralization and immobilization (Albiach et al. 2000). This research indicated that SF treatments with moderate high levels of EC and T-N improved agroecosystem health and nutrient availability, contributing to greater fruit productivity, making of a promising LF for use as a supplemental nutrient amendment. In evaluating the effect of biological nutrient supplements on crop performances, within the confines of an integrated production system, it is often difficult to isolate key variables, such as the effect of individual nutrients and of particular biostimulant compounds. Additional research is thus needed to further understand the physiological mechanism of action of organic supplements, to improve soil biological activity and crop growth.

\section{ACKNOWLEDGMENTS}

The author thanks the Rural Development Administration, Republic of Korea, for providing financial assistance. Additional thanks go to the Department of Horticulture, Daegu Catholic University, Republic of Korea.

\section{FUNDING}

Rural Development Administration

[http://doi.org/10.13039/501100003627]

Grant \#PJ01338806 


\section{REFERENCES}

[RDA] Rural Development Administration. (2010). Analysis methods of soil and plant. National Institute of Agriculture Science. Suwon: RDA Press. [RDA] Rural Development Administration. (2019). Tomato. Suwon: RDA Press.

Ahn, C.-H., Oh, Y.-J., Ock, S.-M., Lee, W.-J., Sohn, S.-I., Kim, M.-H., Na, Y.-E. and Kim, C.-S. (2017). The comparison of community characteristics of ground-dwelling invertebrates according agroecosystem types in the eastern region of the Korean Peninsula. Korean Journal of Applied Entomology, 56, 29-39. https://doi.org/10.5656/KSAE.2016.11.0.056

Albiach, R., Canet, R., Pomares, F. and Ingelmo, F. (2000). Microbial biomass content and enzymatic activities after the application of organic amendments to a horticultural soil. Bioresource Technology, 75, 43-48. https://doi.org/10.1016/S0960-8524(00)00030-4

An, N.-H., Jo, Y.-S., Jo, J.-R., Kim, Y.-K., Lee, Y., Jee, H.-J., Lee, S.-M., Park, K.-L. and Lee, B.-M. (2012). The survey of actual using conditions of farm-made liquid fertilizers for cultivating environment-friendly agricultural products. Korean Journal of Organic Agriculture, $20,345-356$.

Arancon, N. Q., Edwards, C. A., Bierman, P., Metzger, J. D. and Lucht, C. (2005). Effects of vermicomposts produced from cattle manure, food waste and paper waste on the growth and yield of peppers in the field. Pedobiologia, 49, 297-306. https://doi.org/10.1016/j. pedobi.2005.02.001

Badgley, C., Moghtader, J., Quintero, E., Zakem, E., Chappell, M. J., Avilés-Vázquez, K., Samulon, A. and Perfecto, I. (2007). Organic agriculture and the global food supply. Renewable Agriculture and Food Systems, 22, 86-108. https://doi.org/10.1017/S1742170507001640

Bengtsson, J., Ahnström, J. and Weibull, A.-C. (2005). The effects of organic agriculture on biodiversity and abundance: a meta analysis. Journal of Applied Ecology, 42, 261-269. https://doi.org/10.1016/j.agsy.2015.02.009

Caprio, E., Nervo, B., Isaia, M., Allegro, G. and Rolando, A. (2015). Organic versus conventional systems in viticulture: Comparative effects on spiders and carabids in vineyards and adjacent forests. Agricultural Systems, 136, 61-69. https://doi.org/10.1016/j.agsy.2015.02.009

Chaparro, J. M., Badri, D. V. and Vivanco, J. M. (2014). Rhizosphere microbiome assemblage is affected by plant development. The ISME Journal, 8, 790-803. https://doi.org/10.1038/ismej.2013.196

Eaten, R. J., Barbercheck, M., Buford, M. and Smith, W. (2004). Effects of organic matter removal, soil compaction and vegetation control on Collembolan populations. Pedobiologia, 48, 121-128. https://doi.org/10.1016/j.pedobi.2003.10.001

Feber, R. E., Johnson, P. J., Bell, J. R., Chamberlain, D. E., Firbank, L. G., Fuller, R. J., Manley, W., Mathews, F., Norton, L. R., Townsend, M. and Macdonald, D. W. (2015). Organic farming: biodiversity impacts can depend on dispersal characteristics and landscape context. PLoS ONE, 10, e0135921. https://doi.org/10.1371/journal.pone.0135921

Hernández-Herrera, R. M., Santacruz-Ruvalcaba, F., Ruiz-López, M. A., Norrie, J. and Hernández-Carmona, G. (2014). Effect of liquid seaweed extracts on growth of tomato seedlings (Solanum lycopersicum L.). Journal of Applied Phycology, 26, 619-628. https://doi. org/10.1007/s10811-013-0078-4

Thomson, L. J. and Hoffmann, A. A. (2007). Effects of ground cover (straw and compost) on the abundance of natural enemies and soil macro invertebrates in vineyards. Agricultural and Forest Entomology, 9, 173-179. https://doi.org/10.1111/j.1461-9563.2007.00322.x

Kim, D.-I., Kim, S.-G., Ko, S.-J., Kang, B.-R., Choi, D.-S., Lim, G.-H. and Kim, S.-S. (2011). Biodiversity of invertebrate on organic and conventional pear orchards. Korean Journal of Organic Agriculture, 19, 93-107.

Kim, E.-Y., Park, B.-J. and Oh, M.-M. (2013). Availability of slurry composting and biofiltration for cultivation of cherry tomato. Protected Horticulture and Plant Factory, 22, 385-391.

Korea Meteorological Administration. (2019). Statistical analysis of climate. Korea Meteorological Administration, Seoul. [Accessed Jan. 12, 2020]. Available at: https://www.weather.go.kr/weather/climate/average_south.jsp 
Lee, S.-Y., Kim, S.-T., Im, J.-S., Jung, J.-K. and Lee, J.-H. (2013). Comparison of community structure and biodiversity of Arthropos between conventional and organic red pepper fields. Korean Journal of Organic Agriculture, 21, 601-615.

Luttikholt, L. W. M. (2007). Principles of organic agriculture as formulated by the International Federation of Organic Agriculture Movements. NJAS - Wageningen Journal of Life Sciences, 54, 347-360. https://doi.org/10.1016/S1573-5214(07)80008-X.

Marschner, P. (2012). Marschner's mineral nutrition of higher plants. Oxford: Elsevier. https://doi.org/10.1016/C2009-0-63043-9

Miñarro, M., Espadaler, X., Melero, V. X. and Suárez Álvarez, V. (2009). Organic versus conventional management in an apple orchard: effects of fertilization and tree row management on ground dwelling predaceous arthropods. Agricultural and Forest Entomology, 11, 133-142. https://doi.org/10.1111/j.1461-9563.2008.00403.x

Oh, Y.-J., Sohn, S.-I., Song, Y.-I., Kang, S.-B. and Choi, J.-H. (2014). Effects of cover plants on soil microbial community in a organic pear orchard. Korean Journal of Soil Science and Fertilizer, 47, 28-35. https://doi.org/10.7745/KJSSF.2014.47.1.028

Paoletti, M. G., Sommaggio, D., Favretto, M. R., Petruzzelli, G., Pezzarossa, B. and Barbafieri, M. (1998). Earthworms as useful bioindicators of agroecosystem sustainability in orchards and vineyards with different inputs. Applied Soil Ecology, 10, 137-150. https://doi.org/10.1016/ S0929-1393(98)00036-5

Paoletti, M. G. (1999). The role of earthworms for assessment of sustainability and as bioindicators. Agriculture, Ecosystems \& Environment, 74, 137-155. https://doi.org/10.1016/S0167-8809(99)00034-1

Park, J.-S., Lee, M.-J., Lee, S.-Y., Kim, J.-S., Lee, T.-K., Ro, H.-M., Kim, S.-J., Jeon, S.-W., Seo, S.-G., Kim, K.-Y., Lee, G.-H. and Jeong, B.-G. (2015). Effect of mixed liquid fertilization on growth responses of cherry tomatoes and soil chemical properties. Horticultural Science \& Technology, 33, 268-275. https://doi.org/10.7235/hort.2015.14140

Parr, J. F., Papendick, R. I. and Colacicco, D. (1986). Recycling of organic wastes for a sustainable agriculture. Biological Agriculture \& Horticulture, 3, 115-130. https://doi.org/10.1080/01448765.1986.9754466

Refinetti, R. (1984). Behavioral temperature regulation in the pill bug, Armadillidium Vulgare (Isopoda). Crustaceana, 47, 29-43. https:// doi.org/10.1163/156854084X00298

Rosen, C. J. and Allan, D. L. (2006). Exploring the benefits of organic nutrient sources for crop production and soil quality. HortTechnology, 17, 422-430. https://doi.org/10.21273/HORTTECH.17.4.422

Schloss, P. D., Westcott, S. L., Ryabin, T., Hall, J. R., Hartmann, M., Hollister, E. B., Lesniewski, R. A., Oakley, B. B., Parks, D. H., Robinson, C. J., Sahl, J. W., Stres, B., Thallinger, G. G., Van Horn, D. J. and Weber, C. F. (2009). Introducing mothur: Open-source, platform-independent, community-supported software for describing and comparing microbial communities. Applied and Environmental Microbiology, 75, 7537-7541. https://doi.org/10.1128/AEM.01541-09

Todd, J. H., Malone, L. A., McArdle, B. H., Benge, J., Poulton, J., Thorpe, S. and Beggs, J. R. (2011). Invertebrate community richness in New Zealand kiwifruit orchards under organic or integrated pest management. Agriculture, Ecosystems \& Environment, $141,32-38$. https://doi.org/10.1016/j.agee.2011.02.007

Yardim, E. N. and Edwards, C. A. (2003). Effects of organic and synthetic fertilizer sources on pest and predatory insects associated with tomatoes. Phytoparasitica, 31, 324-329. https://doi.org/10.1007/BF02979802 